\title{
Clostridium sufflavum sp. nov., isolated from a methanogenic reactor treating cattle waste
}

\author{
Tomomi Nishiyama, Atsuko Ueki, Nobuo Kaku and Katsuji Ueki \\ Faculty of Agriculture, Yamagata University, Wakaba-machi 1-23, Tsuruoka, Yamagata 997-8555, \\ Japan
}

Correspondence

Atsuko Ueki

uatsuko@tds1.tr.yamagata-u.ac.jp

\begin{abstract}
A strictly anaerobic, mesophilic, cellulolytic bacterial strain, designated CDT-1 ${ }^{\top}$, was isolated from rice-straw residue from a methanogenic reactor treating waste from cattle farms. The isolation was performed using enrichment culture with filter paper as a substrate. Cells stained Gram-negative, but reacted Gram-positively in the $\mathrm{KOH}$ test. Cells were slightly curved rods and were motile by means of peritrichous flagella. The strain produced yellow pigment when grown on filter-paper fragments. Although spore formation was not confirmed microscopically, thermotolerant cells were produced when the strain was grown on filter paper. The optimum temperature for growth was $33{ }^{\circ} \mathrm{C}$ and the optimum $\mathrm{pH}$ was 7.4. Oxidase, catalase and nitrate-reducing activities were absent. The strain utilized xylose, fructose, glucose, cellobiose, xylooligosaccharide, cellulose (filter-paper fragments and ball-milled filter paper) and xylan. The major fermentation products

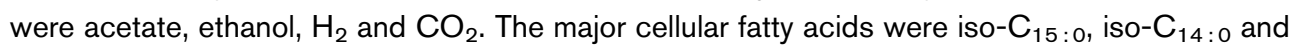
$\mathrm{C}_{16: 0} \mathrm{DMA}$. The cell-wall peptidoglycan contained meso-diaminopimelic acid as the diagnostic diamino acid. The genomic DNA G +C content was 40.7 mol\%. On the basis of $16 \mathrm{~S}$ rRNA gene sequence similarities, strain CDT-1 ${ }^{\top}$ could be placed in cluster III of the genus Clostridium, being closely related to type strains of Clostridium hungatei ( $96.6 \%$ sequence similarity), Clostridium termitidis (96.2\%) and Clostridium papyrosolvens (96.1\%). On the basis of the cellular, physiological and phylogenetic differences between CDT- $1^{\top}$ and its close relatives, this strain represents a novel species of the genus Clostridium, for which the name Clostridium sufflavum sp. nov. is proposed. The type strain is CDT-1 ${ }^{\top}\left(=\mathrm{JCM} 14807^{\top}=\mathrm{DSM} 19573^{\top}\right)$.
\end{abstract}

In anaerobic conditions, cellulose, the most abundant type of organic matter present in plant biomass, is hydrolysed by cellulolytic micro-organisms. The soluble sugars produced are then converted to various organic acids, alcohols, $\mathrm{H}_{2}$ and $\mathrm{CO}_{2}$ by fermentative micro-organisms. Finally, methane is produced by methanogens, which use acetate or $\mathrm{H}_{2}+\mathrm{CO}_{2}$ as major substrates. Thus, the hydrolysis of cellulose is a key reaction for the efficient methanogenesis of waste that is predominantly made up of plant biomass.

Because of their industrial and ecological importance, many cellulolytic, anaerobic bacteria have been isolated and the properties of their cellulolytic enzymes have been extensively investigated. Some species of the genus Clostridium, members of which are anaerobes that produce cellulosomes (highly active cellulolytic and xylanolytic complexes), are classified within Clostridium cluster III on the basis of their 16S rRNA gene sequences (Collins et al., 1994). In this report, the isolation and characterization

The GenBank/EMBL/DDBJ accession number for the 16S rRNA gene sequence of strain $\mathrm{CDT}-1^{\top}$ is $\mathrm{AB} 267266$. of a novel anaerobic, cellulolytic strain belonging to Clostridium cluster III is described.

Strain $\mathrm{CDT}-1^{\mathrm{T}}$ was isolated from a sample of rice-straw residue obtained from a methanogenic reactor treating waste collected from cattle farms (comprising up to 1000 cattle in total) in Betsukai-machi in Hokkaido, Japan. The reactor was a vertical cylindrical type $\left(1500 \mathrm{~m}^{3}\right)$ operated at a mesophilic temperature. Rice-straw used as matting for the cattle was thrown into the reactor, together with cattle faeces and urine, and subjected to waste treatment.

The strain was cultivated anaerobically at $30{ }^{\circ} \mathrm{C}$ (unless otherwise indicated) by using peptone/yeast extract (PY) medium as the basal medium and $\mathrm{O}_{2}$-free mixed gas $\left(\mathrm{N}_{2} /\right.$ $\left.\mathrm{CO}_{2}, 95: 5\right)$ as the headspace, as described by Ueki et al. (2006a). PY medium supplemented with $\left(1^{-1}\right) 0.25 \mathrm{~g}$ each of glucose, cellobiose, maltose and soluble starch, as well as $15 \mathrm{~g}$ agar (Difco), was designated PY4S agar and used for maintenance of the strain in agar slants. PY liquid medium supplemented with $10 \mathrm{~g}$ glucose $1^{-1}$ (PYG medium) was used for the cultivation of the strain for various physiological tests and chemotaxonomic analyses of the cells, unless indicated otherwise (Holdeman et al., 1977). For enrichment culture and isolation of cellulolytic 
bacteria, the concentrations of both peptone and yeast extract in the basal medium were decreased to one-tenth of those in PY medium (1/10PY medium). Media were usually adjusted to $\mathrm{pH} 7.3-7.4$ with $1 \mathrm{M} \mathrm{NaOH}$.

Anaerobic sludge samples obtained from the reactor were filtered through a mesh $(2 \mathrm{~mm}$ pore size $)$ and rice-straw residue remaining on the mesh was collected. The ricestraw samples obtained were washed several times with sterile, anoxic diluent and homogenized in a Waring blender (10 000 r.p.m., $10 \mathrm{~min}$ ) under $\mathrm{N}_{2}$ gas (Kaku et al., 2000). The homogenized samples were successively diluted anaerobically and the enrichment culture was started by inoculating $1 \mathrm{ml}$ 10-fold-diluted samples into $9 \mathrm{ml}$ 1/10PY-p liquid medium (medium containing filter-paper fragments at $2 \mathrm{~g} \mathrm{l}^{-1}$ ). When the filter-paper fragments in the medium had completely disintegrated, $1 \mathrm{ml}$ enrichment culture was transferred to fresh $1 / 10 \mathrm{PY}-\mathrm{p}$ medium $(9 \mathrm{ml})$. After three subcultures of the cellulolytic enrichment, the diluted enrichment cultures were inoculated to anaerobic roll tubes containing 1/10PY-c agar medium (medium containing ball-milled filter paper at $5 \mathrm{~g} \mathrm{l}^{-1}$, as opposed to the paper fragments used in $1 / 10 \mathrm{PY}-\mathrm{p}$ medium). After incubation of the roll tubes for 2-3 weeks, clear zones, indicating decomposition of ball-milled filter paper, appeared in the agar. Some colonies that generated clear zones were picked; strain CDT- $1^{\mathrm{T}}$ was finally obtained after purification using the anaerobic roll-tube method (Hungate, 1966).

Growth of the strain under aerobic conditions was examined as described previously (Ueki et al., 2007). The $\mathrm{KOH}$ test was performed as described by Wallace \& Gates (1986). Spore formation was assessed by observing cells after Gram-staining as well as by means of phase-contrast microscopy. Production of thermotolerant cells was investigated by assessing the growth (in PYG medium) of cells previously exposed to a temperature of $80{ }^{\circ} \mathrm{C}$ for $10 \mathrm{~min}$. The motility of the cells was examined using phase-contrast microscopy and flagella staining was carried out according to Blenden \& Goldberg (1965). Catalase, oxidase and nitrate-reducing activities were determined according to the methods described by Akasaka et al. (2003a, b). Utilization of carbon sources was tested in PY liquid medium with each substrate (monosaccharides, disaccharides, oligosaccharides and sugar alcohols) being added at $10 \mathrm{~g} \mathrm{l}^{-1}$. Other substrates (polysaccharides and glycosides) were added at $5 \mathrm{~g} \mathrm{l}^{-1}$. Utilization of each substrate was determined from growth measured using $\mathrm{OD}_{660}$ values and also by assessing changes to the $\mathrm{pH}$ of the medium after cultivation. Fermentation products were analysed by GC as described previously (Ueki et al., 1986; Akasaka et al., 2003a). Other characteristics were determined using the methods described by Holdeman et al. (1977) and Ueki et al. (2006a, b).

Whole-cell fatty acids were converted to methyl esters according to the method of Miller (1982) and were analysed by GC (Hewlett Packard HP6890 or Hitachi
G-3000) equipped with an HP Ultra 2 column (HewlettPackard). Whole-cell fatty acids were identified from equivalent chain-lengths (Miyagawa et al., 1979; Ueki \& Suto, 1979) according to the protocol of TechnoSuruga Co., Ltd (Shimidu, Japan) (Moore et al., 1994; Ueki et al., 2007). Isoprenoid quinones were extracted and purified as described by Komagata \& Suzuki (1987) and identified by using a mass spectrometer (JMS-SX102A; JEOL). Genomic DNA extracted according to the method described by Akasaka et al. (2003b) was digested with P1 nuclease by using a Yamasa GC kit (Yamasa shoyu) and the $\mathrm{G}+\mathrm{C}$ content was measured by means of HPLC (L-7400; Hitachi) using a $\mu$ Bondapack C18 column $(3.9 \times 300 \mathrm{~mm}$; Waters).

PCR amplification of the almost-complete 16S rRNA gene sequence was carried out using a primer set consisting of 27f and 1492r (Akasaka et al., 2003a). The PCR-amplified $16 \mathrm{~S}$ rRNA gene was sequenced using a Thermo Sequenase cycle sequencing kit (USB Corp.) and a DNA sequencer (4000L; Li-COR). Multiple alignments of the sequences with reference sequences in GenBank were performed with the BLAST program (Altschul et al., 1997). A phylogenetic tree was constructed using the neighbour-joining method (Saitou \& Nei, 1987) with the CLUSTAL W program (Thompson et al., 1994). All gaps and unidentified base positions in the alignments were excluded before sequence assembly.

After about 20 days incubation of a homogenized ricestraw sample inoculated into $1 / 10 \mathrm{PY}$-p liquid medium, the filter-paper fragments in the medium became light yellow and the fibres began to disperse slowly. After further incubation for about 20 days, the filter paper was completely solubilized. The culture was transferred to fresh medium and an enrichment culture capable of degrading the filter paper completely within 20 days incubation was obtained after two more subcultures. Strain CDT- $1^{\mathrm{T}}$ was finally obtained from the culture by picking a colony that produced a clear zone in 1/10PY-c agar medium with the anaerobic agar roll-tube method.

Cells of strain CDT- $1^{\mathrm{T}}$ were slightly curved rods with oval ends, approximately $0.5-0.6 \mu \mathrm{m}$ in diameter and 2.0 $5.0 \mu \mathrm{m}$ in length. Cells occurred singly or in pairs (Fig. 1a). Cells of strain CDT- $1^{\mathrm{T}}$ stained Gram-negative, but reacted Gram-positively in the $\mathrm{KOH}$ test. Cells were motile, as observed under phase-contrast microscopy, and staining showed that the cells had peritrichous flagella (Fig. 1b). Colonies on PY4S agar after 3-4 days anaerobic incubation were white, translucent and irregular with smooth surfaces. Cells of strain CDT- $1^{\mathrm{T}}$ did not grow in air. Although spore formation of the cells was not confirmed microscopically (Fig. 1a) and cells grown in PYG medium and treated at $80{ }^{\circ} \mathrm{C}$ for $10 \mathrm{~min}$ did not grow, cells grown on filter-paper fragments in PY-p medium (PY medium containing filterpaper fragments at $5 \mathrm{~g} \mathrm{l}^{-1}$ ) did grow after heat treatment. Thus, we concluded that cells of strain CDT $-1^{\mathrm{T}}$ produce thermotolerant spores. 

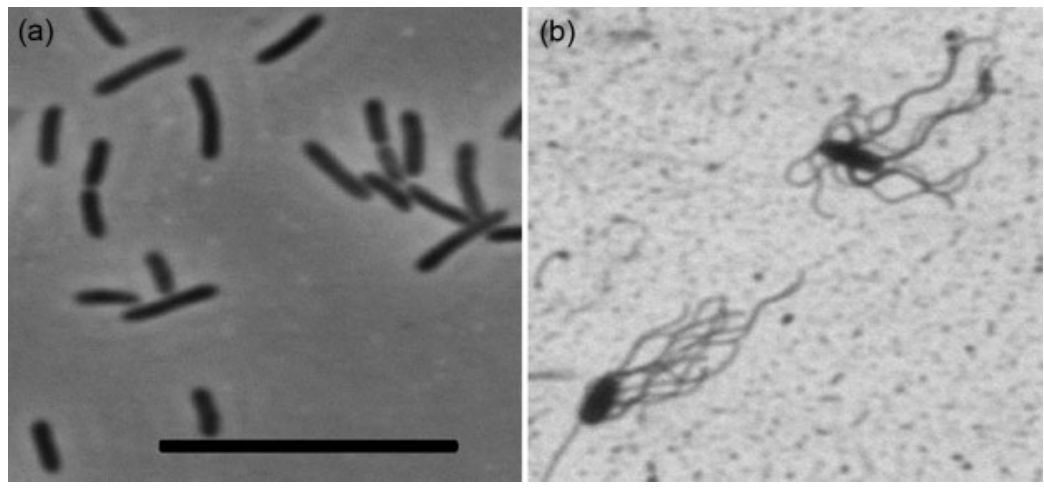

Fig. 1. Photomicrographs of cells of strain CDT-1 ${ }^{\top}$ : (a) phase-contrast photomicrograph of cells on an agar slant containing PY4S medium; (b) photomicrograph of flagellastained cells. Bar, $10 \mu \mathrm{m}$.

Cells were found to be negative for catalase and oxidase activities. The strain utilized xylose, fructose, glucose, cellobiose, xylooligosaccharide, cellulose (fragments of filter paper and filter-paper powder) and xylan as growth substrates. Weak growth was observed on ribose, carboxymethylcellulose and sorbitol. When the strain was cultivated in PY-p medium, filter-paper fragments became yellowish after 7-10 days, at which point visible degradation of the filter paper started. After about 12 days incubation, the filter-paper fragments were completely dispersed in the medium and the $\mathrm{pH}$ of the medium fell to 6.5. After a further 20 days incubation, the final $\mathrm{pH}$ was 5.7. The final $\mathrm{pH}$ of the culture in PYG liquid medium was 5.6. The highest growth rate obtained from among the soluble substrates tested was achieved with cellobiose $\left(\mu=0.064 \mathrm{~h}^{-1}\right)$, while the growth rate on xylose was rather low $\left(\mu=0.035 \mathrm{~h}^{-1}\right)$. The strain did not use arabinose, galactose, mannose, rhamnose, lactose, maltose, melibiose, sucrose, trehalose, melezitose, raffinose, glycogen, inulin, pectin, inositol, mannitol, amygdalin or salicin. The major products of glucose metabolism $\left(10 \mathrm{~g} \mathrm{l}^{-1}\right)$ after 4 days incubation were acetate $\left(11.2 \mathrm{mmol} \mathrm{l}^{-1}\right)$, ethanol $\left(4.0 \mathrm{mmol} \mathrm{l}^{-1}\right), \mathrm{H}_{2}\left(14.7 \mathrm{mmol} \mathrm{l}^{-1}\right)$ and $\mathrm{CO}_{2}$ $\left(11.4 \mathrm{mmol} \mathrm{l}^{-1}\right)$. The strain produced $13.9 \mathrm{mmol}$ acetate $\mathrm{l}^{-1}$ and $8.0 \mathrm{mmol}$ ethanol $\mathrm{l}^{-1}$ from cellobiose $\left(10 \mathrm{~g} \mathrm{l}^{-1}\right)$, and produced $9.7 \mathrm{mmol}$ acetate $\mathrm{l}^{-1}$ and $3.4 \mathrm{mmol}$ ethanol $\mathrm{l}^{-1}$ from filter-paper fragments $\left(5 \mathrm{~g} \mathrm{l}^{-1}\right)$ (30 days incubation). The strain did not reduce nitrate. Aesculin and starch were not hydrolysed. Indole, hydrogen sulfide, lecithinase and lipase were not produced. The strain did not change milk and did not grow in chopped-meat broth.

The temperature range for growth was $20-33{ }^{\circ} \mathrm{C}$, with an optimum at $33{ }^{\circ} \mathrm{C}$. The $\mathrm{pH}$ range for growth was 5.9-8.2, with an optimum at $\mathrm{pH} 7.4$. The $\mathrm{NaCl}$ tolerance of strain CDT- $1^{\mathrm{T}}$ was low: it did not grow in PYG liquid medium containing $\mathrm{NaCl}$ at $5 \mathrm{~g} \mathrm{l}^{-1}$. The growth rate in PYG liquid medium under the above-mentioned optimum conditions $\left(33{ }^{\circ} \mathrm{C}, \mathrm{pH} 7.4\right)$ was $0.073 \mathrm{~h}^{-1}$.

The G+C content of the genomic DNA was $40.7 \mathrm{~mol} \%$. Saturated branched-chain fatty acids and dimethyl acetals were detected as major components of the whole-cell fatty acids of strain $\mathrm{CDT}-\mathrm{1}^{\mathrm{T}}$, which consisted of iso- $\mathrm{C}_{15: 0}$ $(16.1 \%)$, iso- $\mathrm{C}_{14: 0}(14.6 \%), \mathrm{C}_{16: 0}$ DMA (11.5\%), anteiso$\mathrm{C}_{15: 0}(8.7 \%), \mathrm{C}_{14: 0}(7.7 \%)$, iso- $\mathrm{C}_{15: 0}$ DMA $(7.2 \%), \mathrm{C}_{16: 0}$ $(4.8 \%), \mathrm{C}_{14: 0}$ DMA (3.7\%), iso- $\mathrm{C}_{16: 0}(3.2 \%)$ and $\mathrm{C}_{16: 0}$ ALD (2.4\%). The cell-wall peptidoglycan of strain CDT-1 ${ }^{\mathrm{T}}$ contained meso-diaminopimelic acid. Respiratory quinones were not detected.

Analysis of the almost-complete 16S rRNA gene sequence (1436 bp) of strain CDT- $1^{\mathrm{T}}$ indicated that the strain should be assigned to the phylum Firmicutes (Clostridia, Clostridiales, Clostridiaceae). The closest relative of strain CDT- $1^{\mathrm{T}}$ found in GenBank was Clostridium hungatei ATCC $700212^{\mathrm{T}}$ (Monserrate et al., 2001), one of the cellulolytic clostridia constituting Clostridium cluster III (Collins et al., 1994), with a 16S rRNA gene sequence similarity of $96.6 \%$. The next most closely related species were also cellulolytic members of Clostridium cluster III, namely Clostridium termitidis DSM $5398^{\mathrm{T}}$ (sequence similarity of $96.2 \%$ ) (Hethener et al., 1992), Clostridium papyrosolvens DSM $2782^{\mathrm{T}}$ (96.1\%) (Madden et al., 1982), Clostridium josui FERM P-9684 ${ }^{\mathrm{T}}$ (95.9\%) (Sukhumavasi et al., 1988) and Clostridium cellulolyticum ATCC $35319^{\mathrm{T}}$ (95.5\%) (Petitdemange et al., 1984) (Fig. 2).

Some characteristics of strain CDT- $1^{\mathrm{T}}$ and the three most closely related species are compared in Table 1. Although strain $\mathrm{CDT}-1^{\mathrm{T}}$ resembled the other related cellulolytic species morphologically and physiologically, it had some distinctly different characteristics. Cells of strain CDT-1 ${ }^{\mathrm{T}}$ had five to eight peritrichous flagella, but cells of $C$. hungatei have only one or two subpolar flagella (Monserrate et al., 2001) and the cells of C. termitidis have only two to three peritrichous flagella (Hethener et al., 1992). Strain CDT-1 ${ }^{\mathrm{T}}$ did not grow at temperatures above $35{ }^{\circ} \mathrm{C}$, but C. hungatei, C. termitidis and C. papyrosolvens grow at temperatures up to 45,48 and $37{ }^{\circ} \mathrm{C}$, respectively. The substrates utilized by strain CDT- $1^{\mathrm{T}}$ differed from those utilized by related species (Table 1).

Although cells of strain $\mathrm{CDT}-1^{\mathrm{T}}$ appeared to have the Gram-positive type of cell wall on the basis of the $\mathrm{KOH}$ test, cells of strain CDT- $1^{\mathrm{T}}$ and of the related species (except C. termitidis) stain Gram-negative. Cells of strain CDT- $1^{\mathrm{T}}$ and of the related species (except C. papyrosolvens) 


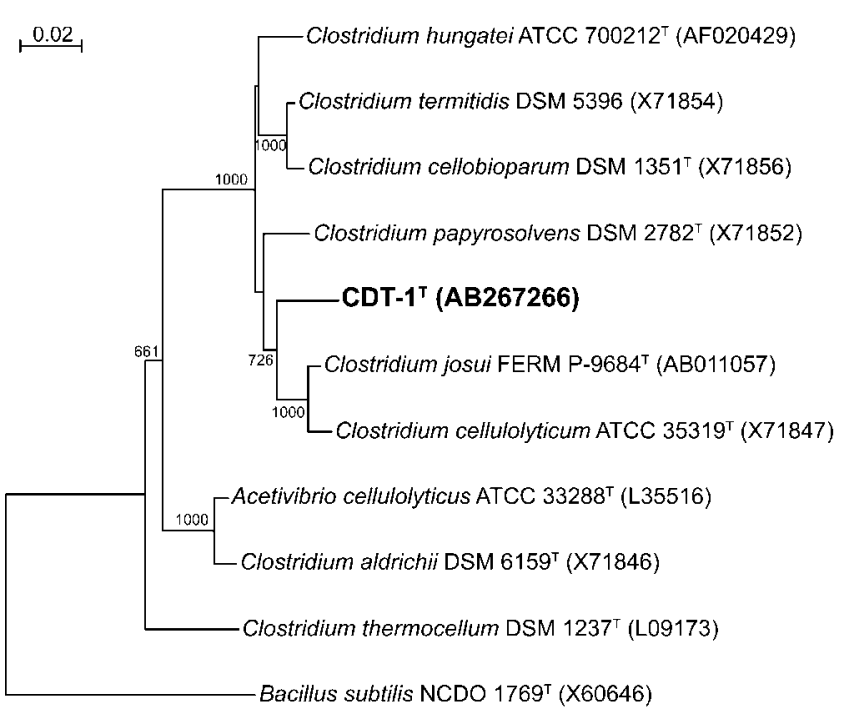

Fig. 2. Neighbour-joining phylogenetic tree, based on $16 \mathrm{~S}$ rRNA gene sequences, showing the relationships of strain CDT- $1^{\top}$ and related species in the genus Clostridium (group III). Bootstrap values (based on 1000 replicates) are shown at the branch points. The sequence of Bacillus subtilis NCDO $1769^{\top}$, which belongs to the class Bacilli, was used as the outgroup. Bar, estimated difference of $2 \%$ in nucleotide sequence positions.

are slightly curved rods. Thus, these cellular characteristics (Gram-negative, slightly curved rods) seem to be properties that are common to the cellulolytic species in Clostridium cluster III. Although cells of Clostridium species generally produce spores and spore formation in species closely related to strain $\mathrm{CDT}^{-1}{ }^{\mathrm{T}}$ has been also confirmed microscopically, we could not observe spores for strain $\mathrm{CDT}_{-1}{ }^{\mathrm{T}}$ (Fig. 1a) and cells grown in PYG medium did not tolerate a temperature of $80{ }^{\circ} \mathrm{C}$ for $10 \mathrm{~min}$. The novel strain may form spores only rarely during growth on soluble saccharides, although thermotolerant cells did occur in cultures grown on filter paper. The rare formation of spores has also been reported for C. cellulolyticum (Petitdemange et al., 1984).

It has been observed that cellulose degradation by Clostridium thermocellum, a thermophilic member of Clostridium cluster III, is accompanied by the production of a pigment called yellow affinity substance (Ljungdahl et al., 1983). It has been suggested that this pigment may facilitate the binding of endoglucanase (produced by the cells) to cellulose, operating as a signal substance helping the cells to attach to cellulose fibres (Ljungdahl et al., 1983). Yellow pigment formation by another cellulolytic clostridium belonging to Clostridium cluster III, i.e. the moderately thermophilic species Clostridium straminisolvens (Kato et al., 2004), is known to occur. The pigment is also produced by a species belonging to Clostridium cluster IV, namely Ruminococcus flavefaciens (Kopečný \& Hodrová, 1997; Willems \& Collins, 1995).

The 16S rRNA gene sequence similarity between strain $\mathrm{CDT}-1^{\mathrm{T}}$ and the most closely related species, C. hungatei, is $96.6 \%$, indicating that it is unlikely that these organisms have more than $70 \%$ identity in terms of DNA-DNA hybridization (Stackebrandt \& Goebel, 1994). Thus, on the basis of cellular and physiological differences between strain $\mathrm{CDT}-1^{\mathrm{T}}$ and closely related species, strain CDT $-1^{\mathrm{T}}$ represents a novel species in Clostridium cluster III, for which the name Clostridium sufflavum sp. nov. is proposed.

Table 1. Some characteristics of strain $\mathrm{CDT}-1^{\top}$ and related species

Strains: 1, CDT-1 ${ }^{\mathrm{T}}$; 2, C. hungatei ATCC $700212^{\mathrm{T}}$ (data from Monserrate et al., 2001); 3, C. termitidis DSM 5398 ${ }^{\mathrm{T}}$ (Hethener et al., 1992); 4 , C. papyrosolvens DSM $2782^{\mathrm{T}}$ (Madden et al., 1982). +, Positive; -, negative; w, weak reaction.

\begin{tabular}{|c|c|c|c|c|}
\hline Characteristic & 1 & 2 & 3 & 4 \\
\hline Isolation source & $\begin{array}{l}\text { Methanogenic reactor treating } \\
\text { waste from cattle farms }\end{array}$ & $\begin{array}{c}\text { Moist soil rich in } \\
\text { decaying plant material }\end{array}$ & $\begin{array}{c}\text { Gut of wood-feeding } \\
\text { termite }\end{array}$ & Estuarine sediments \\
\hline Cell shape & Slightly curved rods & Slightly curved rods & Slightly curved rods & Straight rods \\
\hline Flagellation & Peritrichous & Subpolar & Peritrichous & Peritrichous \\
\hline \multicolumn{5}{|l|}{ Growth temperature $\left({ }^{\circ} \mathrm{C}\right)$} \\
\hline Optimum & 33 & $30-40$ & 37 & $25-30$ \\
\hline Range & $20-33$ & $20-45$ & $20-48$ & $15-37$ \\
\hline Gram-staining & - & - & + & - \\
\hline Aesculin hydrolysis & - & + & + & + \\
\hline \multicolumn{5}{|l|}{ Substrate utilization } \\
\hline Arabinose & - & - & - & + \\
\hline Lactose & - & - & + & - \\
\hline Maltose & - & - & + & - \\
\hline Mannose & - & + & + & - \\
\hline Ribose & $\mathrm{w}$ & - & + & + \\
\hline DNA G $+C$ content $(\mathrm{mol} \%)$ & 40.7 & 40.0 & 39.2 & 30.0 \\
\hline
\end{tabular}




\section{Description of Clostridium sufflavum sp. nov.}

Clostridium sufflavum (suf.fla'vum. L. neut. adj. sufflavum light yellow, referring to the production of a yellow pigment).

Cells are strictly anaerobic, peritrichously flagellated, slightly curved rods with oval ends and are $0.5-0.6 \mu \mathrm{m}$ in diameter and 2.0-5.0 $\mu \mathrm{m}$ in length. Cells occur singly or in pairs. Colonies on PY4S agar are white, translucent and irregular with smooth surfaces. When grown on filter paper as an insoluble cellulose substrate, cells produce a yellow pigment. Cells stain Gram-negative, but react Grampositively in the $\mathrm{KOH}$ test. Although spore formation is not observed for cells grown in PYG liquid and in PY4S agar-slant cultures and cells do not grow after treatment at $80{ }^{\circ} \mathrm{C}$ for $10 \mathrm{~min}$, thermotolerant cells do occur when growth takes place in media with filter-paper fragments. Growth occurs at $20-33{ }^{\circ} \mathrm{C}$ (optimally at $33{ }^{\circ} \mathrm{C}$ ) and $\mathrm{pH}$ 5.9-8.2 (optimally at $\mathrm{pH} 7.4$ ). $\mathrm{NaCl}$ tolerance is very low: growth does not occur in PYG liquid medium containing $\mathrm{NaCl}$ at $5 \mathrm{~g} \mathrm{l}^{-1}$. Negative for oxidase, catalase and nitrate-reducing activities. Xylose, fructose, glucose, cellobiose, xylooligosaccharide, cellulose (filter-paper fragments and ball-milled filter paper) and xylan are utilized as growth substrates. Ribose, carboxymethylcellulose and sorbitol are weakly utilized. Arabinose, galactose, mannose, rhamnose, lactose, maltose, melibiose, sucrose, trehalose, melezitose, raffinose, glycogen, inulin, pectin, inositol, mannitol, amygdalin and salicin are not utilized. Acetate, ethanol, $\mathrm{H}_{2}$ and $\mathrm{CO}_{2}$ are produced as major fermentation products from the saccharides used. Aesculin and starch are not hydrolysed. Indole, hydrogen sulfide, lecithinase and lipase are not produced. Milk is unchanged and no growth occurs in chopped-meat broth. The cell-wall peptidoglycan contains meso-diaminopimelic acid. The major cellular fatty acids are iso- $\mathrm{C}_{15: 0}$, iso- $\mathrm{C}_{14: 0}$ and $\mathrm{C}_{16: 0}$ DMA. No respiratory quinones are present.

The type strain, CDT $-1^{\mathrm{T}}\left(=\mathrm{JCM} 14807^{\mathrm{T}}=\mathrm{DSM} 19573^{\mathrm{T}}\right)$, was isolated from rice-straw residue collected from a methanogenic reactor treating waste originating in cattle farms in Japan. The genomic DNA G + C content of the type strain is $40.7 \mathrm{~mol} \%$.

\section{Acknowledgements}

This work was partly supported by a Grant-in-Aid from the Institute for Fermentation (Osaka, Japan) and also by the Project for Development of Technology for Analysing and Controlling the Mechanism of Biodegrading and Processing supported by the New Energy and Industrial Technology Development Organization (NEDO). We thank Dr T. Hoaki (Taisei Corporation) for the sampling of sludge from the methanogenic reactor.

\section{References}

Akasaka, H., Izawa, T., Ueki, K. \& Ueki, A. (2003a). Phylogeny of numerically abundant culturable anaerobic bacteria associated with degradation of rice plant residue in Japanese paddy field soil. FEMS Microbiol Ecol 43, 149-161.
Akasaka, H., Ueki, A., Hanada, S., Kamagata, Y. \& Ueki, K. (2003b). Propionicimonas paludicola gen. nov., sp. nov., a novel facultatively anaerobic, Gram-positive, propionate-producing bacterium isolated from plant residue in irrigated rice-field soil. Int J Syst Evol Microbiol 53, 1991-1998.

Altschul, S. F., Madden, T. L., Schäffer, A. A., Zhang, J., Zhang, Z., Miller, W. \& Lipman, D. J. (1997). Gapped BLAST and PSI-BLAST: a new generation of protein database search programs. Nucleic Acids Res 25, 3389-3402.

Blenden, D. C. \& Goldberg, H. S. (1965). Silver impregnation stain for Leptospira and flagella. J Bacteriol 89, 899-900.

Collins, M. D., Lawson, P. A., Willems, A., Cordoba, J. J., FernandezGarayzabal, J., Garcia, P., Cai, J., Hippe, H. \& Farrow, J. A. E. (1994). The phylogeny of the genus Clostridium: proposal of five new genera and eleven new species combinations. Int J Syst Bacteriol 44, 812-826.

Hethener, P., Brauman, A. \& Garcia, J. L. (1992). Clostridium termitidis sp. nov., a cellulolytic bacterium from the gut of the woodfeeding termite, Nasutitermes lujae. Syst Appl Microbiol 15, 52-58.

Holdeman, L. V., Cato, E. P. \& Moore, W. E. C. (1977). Anaerobe Laboratory Manual, 4th edn. Blacksburg, VA: Virginia Polytechnic Institute and State University.

Hungate, R. E. (1966). The Rumen and Its Microbes. New York: Academic Press.

Kaku, N., Ueki, A., Fujii, H. \& Ueki, K. (2000). Methanogenic activities on rice roots and plant residue and their contributions to methanogenesis in wetland rice field soil. Soil Biol Biochem 32, 2001-2010.

Kato, S., Haruta, S., Cui, Z. J., Ishii, M., Yokota, A. \& Igarashi, Y. (2004). Clostridium straminisolvens sp. nov., a moderately thermophilic, aerotolerant and cellulolytic bacterium isolated from a cellulose-degrading bacterial community. Int J Syst Evol Microbiol 54, 2043-2047.

Komagata, K. \& Suzuki, K. (1987). Lipid and cell-wall analysis in bacterial systematics. Methods Microbiol 19, 161-207.

Kopečný, J. \& Hodrová, B. (1997). The effect of yellow affinity substance on cellulases of Ruminococcus flavefaciens. Lett Appl Microbiol 25, 191-196.

Ljungdahl, L. G., Pettersson, B., Eriksson, K. E. \& Wiegel, J. (1983). A yellow affinity substance involved in the cellulolytic system of Clostridium thermocellum. Curr Microbiol 9, 195-200.

Madden, R. H., Bryder, M. J. \& Poole, N. J. (1982). Isolation and characterization of an anaerobic, cellulolytic bacterium, Clostridium papyrosolvens sp. nov. Int J Syst Bacteriol 32, 87-91.

Miller, L. T. (1982). Single derivatization method for routine analysis of bacterial whole-cell fatty acid methyl esters, including hydroxyl acids. J Clin Microbiol 16, 584-586.

Miyagawa, E., Azuma, R. \& Suto, E. (1979). Cellular fatty acid composition in Gram-negative obligately anaerobic rods. J Gen Appl Microbiol 25, 41-51.

Monserrate, E., Leschine, S. B. \& Canale-Parola, E. (2001). Clostridium hungatei sp. nov., a mesophilic, $\mathrm{N}_{2}$-fixing cellulolytic bacterium isolated from soil. Int J Syst Evol Microbiol 51, 123-132.

Moore, L. V. H., Bourne, D. M. \& Moore, W. E. C. (1994). Comparative distribution and taxonomic value of cellular fatty acids in thirty-three genera of anaerobic Gram-negative bacilli. Int J Syst Bacteriol 44, 338347.

Petitdemange, E., Caillet, F., Giallo, J. \& Gaudin, C. (1984). Clostridium cellulolyticum sp. nov., a cellulolytic, mesophilic species from decayed grass. Int J Syst Bacteriol 34, 155-159.

Saitou, N. \& Nei, M. (1987). The neighbor-joining method: a new method for reconstructing phylogenetic trees. Mol Biol Evol 4, 406425 . 
Stackebrandt, E. \& Goebel, B. M. (1994). Taxonomic note: a place for DNA-DNA reassociation and $16 \mathrm{~S}$ rRNA sequence analysis in the present species definition in bacteriology. Int J Syst Bacteriol 44, 846849.

Sukhumavasi, J., Ohmiya, K., Shimizu, S. \& Ueno, K. (1988). Clostridium josui sp. nov., a cellulolytic, moderate thermophilic species from Thai compost. Int J Syst Bacteriol 38, 179-182.

Thompson, J. D., Higgins, D. G. \& Gibson, T. J. (1994). CLUSTAL W: improving the sensitivity of progressive multiple sequence alignment through sequence weighting, position-specific gap penalties and weight matrix choice. Nucleic Acids Res 22, 4673-4680.

Ueki, A. \& Suto, T. (1979). Cellular fatty acid composition of sulfatereducing bacteria. J Gen Appl Microbiol 25, 185-196.

Ueki, A., Matsuda, K. \& Ohtsuki, C. (1986). Sulfate reduction in the anaerobic digestion of animal waste. J Gen Appl Microbiol 32, 111-123.

Ueki, A., Akasaka, H., Suzuki, D. \& Ueki, K. (2006a). Paludibacter propionicigenes gen. nov., sp. nov., a novel strictly anaerobic, Gramnegative, propionate-producing bacterium isolated from plant residue in irrigated rice-field soil in Japan. Int J Syst Evol Microbiol 56, 39-44.
Ueki, A., Akasaka, H., Suzuki, D., Hattori, S. \& Ueki, K. (2006b). Xylanibacter oryzae gen. nov., sp. nov., a novel strictly anaerobic, Gram-negative, xylanolytic bacterium isolated from rice-plant residue in flooded rice-field soil in Japan. Int J Syst Evol Microbiol 56, 22152221.

Ueki, A., Akasaka, H., Suzuki, D., Satoh, A. \& Ueki, K. (2007). Prevotella paludivivens sp. nov., a novel strictly anaerobic, Gramnegative, hemicellulose-decomposing bacterium isolated from plant residue and rice roots in irrigated rice-field soil. Int J Syst Evol Microbiol 57, 1803-1809.

Wallace, W. H. \& Gates, J. E. (1986). Identification of Eubacteria isolated from leaf cavities of four species of the N-fixing Azolla fern as Arthrobacter Conn and Dimmick. Appl Environ Microbiol 52, 425429.

Willems, A. \& Collins, M. D. (1995). Phylogenetic analysis of Ruminococcus flavefaciens, the type species of the genus Ruminococcus, does not support the reclassification of Streptococcus hansenii and Peptostreptococcus productus as ruminococci. Int J Syst Bacteriol 45, 572-575. 